\title{
АДМІНІСТАРТИВНО-ПРАВОВЕ РЕГУЛЮВАННЯ СТАТУСУ ДЕРЖАВНИХ СЛУЖБОВЦІВ СУДОВИХ ОРГАНІВ УКРАЇНИ
}

Бабчук А. Д.

У науковій статmі досліджені питання адміністративно-правового регулювання статусу державних службовців судових органів України. Проаналізовано понятійний апарат і особливості функціонування апарату суду. 3 урахуванням проведеного аналізу законодавчої бази розроблені пропозиції щодо необхідності вдосконалення нормативно-правових актів, які регулюють статус державного службовця - працівника суду.

Ключові слова: адміністративно-правовий статус, anapam суду, державний службовець, суд, судові органи, проходження державної служби.

В научной статье исследованы вопросы административно-правового регулирования статуса государственных служащих судебных органов Украины. Проанализированы понятийный annарат и особенности функционирования аппарата суда. С учетом проведенного анализа законодательной базы разработаны предложения о необходимости совершенствования нормативно-правовых актов, регулирующих статус государственного служащего - работника суда.

Ключевые слова: административно-правовой статус, anпарат суда, государственный служащий, суд, судебные органы, прохождение государственной службы.

Babchuk A. D. Administrative and legal regulation of the status of civil servants at the judicial organs of Ukraine

The scientific article examines the general theoretical issues of administrative and legal regulation of the status of civil servants of the judiciary of Ukraine. The conceptual apparatus on the chosen topic and the development of scientific thought are analyzed. The legal categories: "legal status of a civil servant", "administrative and legal status of judicial bodies", "administrative and legal regulation", "court staff", others are studied. It is established that most of the definitions are not enshrined in law. Among them are such as "the judiciary", "the judicial system of Ukraine", "judicial system", "judicial system", "justice”, "justice", "judicial authorities" and so on.

The structure of the administrative and legal status of the subject is analyzed. Its division of general, special and individual legal status is substantiated.

The normative-legal base, which regulates the issue of civil service in court, has been studied. The peculiarities of the functioning of the court staff and the evaluation of the results of the official activity of the court staff have been established. Emphasis is placed on the fact that the professionalism of court staff should be one of the main criteria for evaluating the activities of the judiciary.

Selected categories of court employees who are civil servants. The classification of court staff depending on their place in the training process and conditions for the administration of justice is given.

The main functional responsibilities of court staff are explored. Taking into account the analysis of the legal framework, proposals have been developed on the need to improve the regulations governing the status of civil servants - court employees. The necessity of developing uniform criteria for evaluating the activity of civil servants of the court staff is substanti- ated, taking into account the peculiarities of serving in court, as well as the specifics of the implementation of judicial functions.

Key words: administrative and legal status, court staff, civil servant, court, judicial bodies, civil service.

Постановка проблеми та їі актуальність. Національна судова система вже тривалий час перебуває у стадії динамічного реформування. За останні роки ухвалено низку нормативно-правових актів, відповідно до яких ця сфера зазнала істотних змін [1].

Так, 30 вересня 2016 р. набрали чинності Закон України № 1401-VIII «Про внесення змін до Конституції України (щодо правосуддя)» [2] та Закон України № 1402-VIII «Про судоустрій і статус суддів» (нова редакція) [3].

Відповідно до Закону України «Про несення змін до Конституції України (щодо правосуддя)» [2], скасовано інститут «призначення судді на посаду вперше»; підвищено віковий та професійний ценз щодо кандидатів на посаду судді; встановлено новий порядок формування Вищої ради правосуддя тощо.

Законом України «Про судоустрій і статус суддів» запропоновано такі новели, як перехід до триланкової системи судів; упровадження нових механізмів для стимулювання забезпечення доброчесної поведінки суддів із залученням громадськості; закріплення обов'язку судді (кандидата на посаду судді) подавати декларацію родинних зв'язків, декларацію доброчесності; запровадження відкритих конкурсів на зайняття посади суддів апеляційних, вищих спеціалізованих судів та Верховного Суду з допуском до них осіб, що не мають суддівського стажу, та ін. [4]. Утворено Верховний суд, Вищий антикорупційний суд, Вищий суд з питань інтелектуальної власності.

У процесі судової реформи в основному увага законодавця приділена вдосконаленню правового статусу судді, організації судового процесу, переформуванню судових органів, здійсненню правосуддя на конституційних принципах відкритості, доброчесності тощо.

Однак ключовим елементом судової системи $\epsilon$ апарат суду, який формується з державних службовців. Саме від професійності, кваліфікації та мотивації державних службовців залежать ефективність та швидкість роботи суду, якісне виконання покладених на суд завдань і функцій.

У зв'язку із цим питання вдосконалення адміністративно-правового врегулювання статусу державного службовця в судовій системі $є$ важливим і актуальним для наукового дослідження.

Статус державних службовців судових органів України регулюється водночас положеннями Закону України «Про державну службу», законодавством про 
судоустрій і статус суддів, низкою інших нормативно-правових актів, що, у свою чергу, зумовлює необхідність поглибленого дослідження особливостей адміністративно-правового регулювання діяльності даної категорії посадовців [6].

Особливого значення набуває аналіз проблемних питань, пов'язаних із практичною реалізацією процедур проходження державної служби в умовах реформування судової системи й інституту державної служби.

Аналіз останніх досліджень і публікацій. Окремі питання, пов'язані з адміністративно-правовим регулюванням статусу державних службовців судових органів України, досліджували у своїх наукових роботах В. Авер'янов, Н. Грінівецька, С. Ківалов, О. Крупчан, В. Луговий, Д. Майборода, Н. Нижник, В. Олуйко й інші. Однак у системі судових органів, де основні принципи розвитку інституту державної служби повинні запроваджуватися з урахуванням специфіки діяльності апаратів судів, ці питання поки що не знайшли комплексного вирішення.

Окремі положення даної проблематики досліджувалися в роботах В. Капустинського, але зазначеним автором розглядалися лише питання діяльності апарату суду в контексті загальнодержавних та інтеграційних процесів у сфері державної служби.

Чимало робіт науковців присвячено окремому дослідженню таких загальнотеоретичних понять, як «правове регулювання» (О. Мельник, В. Ткаченко, $Є$. Ручкін та інші), «адміністративного-правове регулювання» (В. Развадський, В. Петрова й А. Семенов, В. Темерецький, І. Шопіна й інші).

Мета статті полягає в тому, щоб на основі аналізу теоретичних, організаційно-правових засад, юридичної природи, сутності, змісту адміністративно-правового регулювання статусу державних службовців судових органів України розробити пропозиції щодо вдосконалення чинного законодавства України та практики його реалізації у сфері судового менеджменту в кореляції із сучасними критеріями оцінки державної служби в судових органах.

Той факт, що статус державних службовців судових органів України, окрім Закону України «Про державну службу» регулюється додатково ще й законодавством про судоустрій і статус суддів, зумовлює необхідність поглибленого дослідження особливостей адміністративно-правового регулювання діяльності даної категорії посадовців [6]. Отже, існує потреба у проведенні ґрунтовного якісного дослідження в цій області адміністративно-правового регулювання.

Виклад основного матеріалу. Конституцією України реґламентовано, що державна влада в Україні здійснюється на засадах їі поділу на законодавчу, виконавчу та судову [5]. У теорії даний поділ визнають принципами поділу.

Основною метою поділу державної влади на три основні гілки $\epsilon$ необхідність розмежування напрямів діяльності, $з$ одночасним забезпеченням принципу «стримувань та противаг». Важливим моментом $\epsilon$ також недопущення узурпації однією гілкою влади іншої влади. Для досягнення основної мети - побудови правової демократичної держави - усі гілки влади повинні працювати як єдиний організм у межах наданої їм компетенції.

На судову владу покладено обов'язок забезпечити право кожного на справедливий суд, його функціону- вання на конституційних засадах верховенства права; рівності всіх учасників судового процесу перед законом і судом; забезпечення доведеності вини; змагальності сторін та свободи в наданні ними суду своїх доказів і в доведенні перед судом їхньої переконливості; підтримання публічного обвинувачення в суді прокурором; забезпечення обвинуваченому права на захист; гласності судового процесу та його повного фіксування технічними засобами; розумності строків розгляду справи судом; забезпечення права на апеляційний перегляд справи та, у визначених законом випадках, - на касаційне оскарження судового рішення; обов'язковість судового рішення [5].

В. Развадський визначає адміністративно-правове регулювання як комбінацію способів правового регулювання, у якій переважають зобов'язання та заборони. Ця комбінація формується через наділення учасників правовідносин суб'єктивними юридичними правами й покладання на них обов'язків шляхом визначення та закріплення у правових актах певних правил поведінки внаслідок правотворчої діяльності уповноважених на це органів (посадових осіб) [27; 28].

Проходження державної служби в судових органах реґламентовано Конституцією України [5], Законом України «Про державну службу» [6] (з урахуванням особливостей, визначених Законом України «Про судоустрій і статус суддів» [3], Законом України «Про запобігання корупції» [7], Кодексом законів про працю України [8], іншими кодексами та законами України, постановами Кабінету Міністрів України, підзаконними нормативно-правовими актами, актами локальної дії (зокрема, Положенням про апарат суду, рішеннями, наказами й розпорядженнями голови суду тощо).

Під час дослідження обраної теми насамперед необхідно зазначити, що в Законі України «Про судоустрій і статус суддів» та інших нормативно-правових актах уживаються такі терміни, як: «судова влада», «система судоустрою України», «судова система», «судоустрій», «правосуддя», “судочинство», «судові органи» тощо. Водночас більшість цих понять у законах не визначаються. Відсутність єдиного підходу на законодавчому рівні до деяких із вищенаведених понять призводить до різного їх розуміння на практиці, а іноді - навіть неоднакового застосування. 3 метою кращого розуміння теми наукового дослідження спробуємо розкрити основні з вищенаведених понять.

За допомогою аналізу наукових досліджень визначимось, уживання яких визначень недоречне в контексті розгляду питання щодо працівників суду, які наділені статусом державних службовців.

Судова влада розглядається як незалежна і самостійна гілка державної влади, яка здійснюється судами [9]. Більшість сучасних дослідників судової влади визначають іï як сукупність судів, які здійснюють правосуддя. Інші ототожнюють судову владу з методом іiі реалізації - правосуддям.

На думку Ю. Грошевского й І. Марочкіна, поняття «судова влада» $\mathrm{i}$ «правосуддя» $\epsilon$ близькими, але не тотожними. Основу судової влади становить сукупність судових органів, наділених відповідними повноваженнями. Головним призначенням цих органів $\epsilon$ врегулювання правових конфліктів: між людьми, людиною і державою, різними структурами держави. Суб'єктом судової влади $€$ суд, наділений призначеними лише 
йому повноваженнями впливати на поведінку людей і соціальні процеси. Отже, судова влада - це специфічна гілка державної влади, яка здійснюється уповноваженими на це державними органами - судами - i призначенням якої $\epsilon$ врегулювання правових конфліктів та здійснення судового контролю [10, с. 4-6].

Відповідно до Закону України «Про судоустрій і статус суддів», судову владу реалізовують судді та, у визначених законом випадках, присяжні шляхом здійснення правосуддя в рамках відповідних судових процедур [3]. Отже, законодавець чітко визначає коло суб'єктів, що реалізують судову владу. Цими суб'єктами є судді та присяжні (у деяких випадках).

Законом України «Про судоустрій і статус суддів» визначено, що правосуддя в Україні здійснюється виключно судами та відповідно до визначених законом процедур судочинства. Делегування функцій судів, а також привласнення цих функцій іншими органами чи посадовими особами не допускаються [3]. 3 огляду на зазначене можна дійти висновку, що коли говорять про правосуддя, то йдеться про чітко визначених суб' $є$ ктів - суддів, наділених виключною компетенцією здійснювати правосуддя відповідно до визначених законом процедур судочинства.

І. Назаров уважає, що судова система - це система спеціальних державних органів - судів, які $\epsilon$ носіями судової влади, створені для задоволення потреби в розгляді та вирішенні правових спорів, що виникають, мають загальні завдання, принципи організації та діяльності, відповідають рівню соціально-економічного розвитку суспільства [11, с. 11].

На думку Н. Квасневської, автор цілком виправдано організаційні межі судової системи окреслює судами як спеціалізованими установами, уповноваженими здійснювати правосуддя [14].

Подібної думки дотримується М. Фоміна, яка пропонує визначати судову систему як єдину, взаємозалежну, ієрархічно побудовану сукупність судів у державі [12, с. 68]. Отже, частина науковців $\epsilon$ прихильниками концепції, за якою судову систему створюють виключно суди України.

Натомість у вітчизняній правовій теорії наявні й інші підходи до визначення категорії «судова система». Так, на думку Р. Куйбіди, судова система - це сукупність судів, органів та установ, що їх обслуговують [13, с. 6, 14].

Судова система розглядається І. Туркіною як обумовлена Конституцією та законами сукупність судів, організованих на демократичних принципах з урахуванням національно-державного й адміністративно-територіального устрою держави [15]. Отже, по суті йдеться про сукупність судових органів держави, упорядковану за допомогою нормативного масиву, але аж ніяк не про систему в методологічному розумінні. Якщо ж таку сукупність визначити як єдину та взаємозалежну, можемо отримати зміст поняття «система судів», але не поняття «судова система» [12].

Підтримуємо думку Р. Куйбіди та вважаємо, що судова система - це сукупність не лише судів, а й органів і установ, що їх обслуговують.

У дослідженні напрямів оптимізації судоустрою України Л. Москвич зазначає, що судоустрій являє собою організаційне оформлення (організаційна побудова) судової системи [16]. Щодо шляхів удосконалення організаційних умов для належного виконання основного призначення суду дослідниця констатує, що пошук оптимальної для нашої держави моделі судоустрою ще не завершено [12].

Судоустрій будується за принципами територіальності, спеціалізації та інстанційності. Найвищим судом у системі судоустрою $є$ Верховний Суд. Систему судоустрою становлять: 1) місцеві суди; 2) апеляційні суди; 3) Верховний Суд [3].

3 визначення, наведеного в Законі України «Про державну службу», випливає, що державним службовцем $\epsilon$ громадянин України, який обіймає посаду державної служби в органі державної влади, іншому державному органі, його апараті (секретаріаті) (далі - державний орган), одержує заробітну плату державним коштом та здійснює встановлені для цієї посади повноваження, безпосередньо пов'язані з виконанням завдань і функцій такого державного органу, а також дотримується принципів державної служби [6].

П. Василенков охарактеризував державний орган як організацію, яка становить частину державного апарату, яка має певну компетенцію, територіальний масштаб діяльності, створюється в законодавчо визнаному порядку, володіє певним методом роботи, наділена повноваженнями виступати від імені держави й покликана вирішувати їі завдання і виконувати основні функції [25, с. 41]

Суду притаманні всі ознаки державного органу, які, крім того, доповнюються і власними рисами, що виникають через специфічність основної функції суду здійснення правосуддя [26].

У Законі України «Про державний захист працівників суду і правоохоронних органів» наводиться визначення терміна «правоохоронні органи», а точніше, органів, які віднесені до цієї категорії.

Відповідно до цього Закону, захисту підлягають судді Конституційного Суду України, судді та працівники апаратів судів, працівники правоохоронних органів, зазначені в ч. 1 цього пункту, а також співробітники кадрового складу розвідувальних органів України, співробітники Служби судової охорони та інші.

3 огляду на вищенаведене, можна говорити, що працівниками суду є судді, працівники апаратів, інших судових органів. Однак уважаємо, що це визначення потребує додаткового дослідження та систематизації працівників за об'ємом їхніх повноважень, спеціалізацією суддів тощо, а категорія державних службовців повинна зайняти окрему нішу в такій класифікації, оскільки наділена суттєвими відмінностями.

Особливостям проходження державної служби в окремих державних органах присвячено розд. X Закону «Про державну службу».

Відповідно до ст. 91 Закону України «Про державну службу», дія цієї статті поширюється, серед іншого, на керівників апаратів (секретаріатів), допоміжних органів, утворених Президентом України, Конституційного Суду України, Верховного Суду, вищих спеціалізованих судів, Вищої ради правосуддя, Вищої кваліфікаційної комісії суддів України. Керівники апаратів (секретаріатів) державних органів, зазначених у ч. 1 ст. 91 вищезазначеного Закону, крім Керівника Секретаріату Конституційного Суду України, які призначаються на посаду в порядку, визначеному законом, а керівники апаратів (секретаріатів) судів, органів та установ системи правосуддя - з особливостями, передбаченими законодавством про судоустрій і статус суддів [6;17]. 
Питанням державної служби в системі правосуддя, оплаті праці та соціальним гарантіям присвячено ст. 150 Закону України «Про судоустрій та статус суддів», у якій, серед іншого, передбачається, що призначення на посади державних службовців, працівників, які виконують функції з обслуговування, оплата праці та соціальні гарантії працівників апаратів місцевих, апеляційних судів, вищих спеціалізованих судів, апарату Верховного Суду, секретаріатів Вищої ради правосуддя і Вищої кваліфікаційної комісії суддів України, Державної судової адміністрації України регулюються нормами законодавства про державну службу з урахуванням особливостей, визначених цим Законом [3].

А. Макаровець вказує на те, що в Законі України «Про державну службу» невизначеним залишається питання віднесення до посад державної служби інших працівників апаратів Верховного Суду України, вищих спеціалізованих судів, апеляційних судів та судів першої інстанції, оскільки не міститься прямої вказівки на групу/підгрупу, до якої потрібно відносити ту чи іншу посаду в апараті того чи іншого суду [16, с. 53].

Окрім цього, на законодавчому рівні немає визначення поняття «апарат суду», діяльність якого спрямована в основному на здійснення організаційного забезпечення діяльності судів. Апарат суду має унікальну структуру, є за своєю природою допоміжним органом в системі правосуддя. Значення апарату як допоміжного елемента судової системи не можна недооцінювати, оскільки результати роботи апарату суду $\epsilon$ однією з передумов забезпечення якості й ефективності діяльності суду, починаючи від прийняття позовних заяв і закінчуючи оформленням виконавчих документів.

Не вирішується це питання і на рівні Типового положення про апарат суду, затвердженого наказом Державної судової адміністрації України від 8 лютого 2019 р. № 131 [19], та низки Типових посадових інструкцій працівників апарату місцевого загального суду, які здебільшого лише дублюють фрагментарні норми Закону України «Про судоустрій і статус суддів».

Основні функції апарату суду перелічені в розд. II Типового положення про апарат суду, затвердженого наказом Державної судової адміністрації України від 8 лютого 2019 р. № 131. До них, наприклад, належать: створення належних умов діяльності суду для ефективного виконання суддями покладених на них повноважень; здійснення організаційного, інформаційно-довідкового й документального забезпечення підготовки справ і матеріалів для розгляду суддями; організація та забезпечення ведення діловодства в суді тощо [19].

Ю. Юрченко зазначає, що апарат суду - це суб'єкти публічної адміністрації, державні службовці, які здійснюють свою діяльність згідно із законами України «Про судоустрій та статус суддів» та «Про державну службу». Вони разом з іншими суб'єктами публічної адміністрації забезпечують право фізичних і юридичних осіб на справедливе й гуманне адміністративне судочинство, однак не безпосередньо, а шляхом забезпечення суддям умов для ефективного здійснення судочинства [24, с. 56].

Працівників апарату суду залежно від місця у процесі підготовки й умов для здійснення правосуддя можна поділяти на: а) керівництво (керівники апарату суду та його заступники); б) спеціалістів (консультанти, секретарі судового засідання, помічники суддів, судові розпорядники); в) технічний персонал (діловоди, опе- ратори комп'ютерного набору, архіваріуси, завідувачі господарством, бібліотекарі й ін.); г) обслуговуючий персонал (кур'єри, прибиральниці, робітники з обслуговування будівлі, двірники) [23, с. 67-68].

Аналізуючи далі норми Закону України «Про державну службу», знаходимо ще одну статтю (ст. 22), відповідно до якої передбачено, що особливості проведення конкурсу державних службовців на посади в органах судової влади визначаються законом [6]. Водночас законодавцем не уточнено, у якому саме законі.

Особливостями може також характеризуватися проведення оцінювання результатів службової діяльності державних службовців в апараті судової влади. Так, відповідно до ст. 44 Закон України «Про державну службу», зазначено, що керівник державної служби в апараті органу законодавчої та судової влади може проводити оцінювання результатів службової діяльності державних службовців з урахуванням особливостей проходження державної служби в апараті таких органів [6]. Необхідно зауважити, що проведення оцінювання результатів службової діяльності державних службовців з урахуванням особливостей проходження державної служби в апараті таких органів $\epsilon$ правом, а не обов'язком керівника державної служби в апараті органу судової влади.

Одним з основних критеріїв оцінювання діяльності судових органів має бути професіоналізм працівників апарату суду.

У ст. 94 Закону України «Про судоустрій і статус суддів» передбачено, що члени Вищої кваліфікаційної комісії суддів України повинні у своїй діяльності та поза iї межами дотримуватися найвищих стандартів етичної поведінки, зокрема й принципів та правил етики, які застосовуються до суддів [3].

Уважаємо, що дане правило щодо зобов'язання дотримуватись найвищих стандартів етичної поведінки повинно застосовуватись до всіх працівників суду, зокрема й до державних службовців. Такий підхід допоможе підвищити рівень довіри до суду та покращити його імідж.

Я. Золотарьова вказує на те, що правовий статус державних службовців судових органів має декілька зрізів - рівнів: перший зріз становлять елементи правового статусу, визначені в Законі України «Про державну службу»; другий - визначені Законом України «Про судоустрій та статус суддів»; третій зріз визначається посадою, яку обіймає певний службовець [20, с. 81], яка має бути визначена відповідною Типовою посадовою інструкцією. Кожному з рівнів відповідає низка прав, обов'язків і обсяг відповідальності державного службовця в апараті суду.

Адміністративно-правовий статус судових органів можна визначити як закріплену в нормах адміністративного законодавства систему взаємопов'язаних і взаємозумовлених елементів, що визначають правове становище судів, а також інших судових органів (судове самоврядування, Державна судова адміністрація та ін.) в адміністративно-правових відносинах з іншими суб'єктами, між собою, а також характеризують їхню роль і призначення в системі державних органів.

Під час розгляду адміністративно-правового статусу судових органів варто виходити з неоднорідності його структури, що зумовлює потребу виділення окремих, проте тісно пов'язаних один з одним елементів. Харак- 
теристика кожного з них дозволяє більш глибоко дослідити особливості адміністративно-правового статусу судових органів і визначити їхнє місце в системі інших органів державної влади.

Н. Захорольних уважає, що у структурі адміністративно-правового статусу суб'єкта можна виділити загальний, спеціальний та індивідуальний правовий статус. Учений зазначає, що саме індивідуальний правовий статус відображає особливості правового становища суб'єкта й уособлює його права й обов'язки за участю в конкретних правовідносинах [21].

Правовий статус державних службовців судових органів передбачає: 1) наявність владних повноважень як внутрішньоорганізаційного, так і зовнішнього характеру; 2) можливість виступати в межах своєї компетенції від імені держави під час здійснення нагляду за додержанням і правильним застосуванням законів органами державної влади й органами місцевого самоврядування, фізичними та юридичними особами, підприємствами, установами й організаціями; 3) наявність встановлених обмежень як під час вступу на державну службу, так і під час її проходження; 4) наявність гарантій соціально-правового захисту; 5) підвищену відповідальність як за власні дії, так і за діяльність (бездіяльність) підлеглих їм працівників [20, с. 82].

Висновки. Судова національна система має розгалужену структуру. Здебільшого законодавцем приділяється увага вдосконаленню правового статусу судді, підвищенню критеріїв добору доброчесних суддів, відкритості та доступу до правосуддя кожного громадянина, тобто реформуванню системи. Водночас питання адміністративно-правового регулювання статусу державного службовця судових органів залишено без належної уваги.

Загальні засади правової реґламентації проходження державної служби в судових органах відображено в законах України «Про державну службу» та «Про судоустрій і статус суддів», Типовому положенні про апарат місцевого, апеляційного судів і Типових посадових інструкцій працівників апарату місцевого загального суду, які повною мірою не враховують особливостей, притаманних роботі державних службовців в апаратах судів і в усій галузі судової влади загалом.

Окрім цього, у нормативно-правових актах уживаються різні терміни, визначення яких не наводяться, що ускладнює їх розуміння та практичне застосування. 3 урахуванням вищенаведеного, вбачається нагальна необхідність удосконалення адміністративно-правового регулювання статусу державних службовців апарату суду.

У зв'язку з цим уважаємо за необхідне внести зміни в Закон України «Про судоустрій і статус суддів», доповнити його окремим розділом «Загальні положення» та статтею «Визначення термінів», у якій, серед іншого, визначити такі поняття, як: «апарат суду», «секретаріат суду», «органи та установи системи правосуддя», «працівники апарату суду», «судові органи», «судова система», судоустрій», «правосуддя», «суд», «державні службовці судових органів» тощо.

Окрім цього, варто розробити єдині критерії оцінювання діяльності державних службовців апарату суду 3 урахуванням особливостей проходження служби в суді, а також специфіки реалізації функцій правосуддя.

\section{Література}

1. Анцупова Т. Судова система. Якою вона була i якою стане? URL: http://sudovareforma.org/institution/ sudova-systema-yakoyu-bula-yakoyu-stane/ (дата звернення: 22.06.2020).

2. Про внесення змін до Конституції України (щодо правосуддя) : Закон України від 2 червня 2016 р. № 1401-VIII. URL: https://zakon.rada.gov.ua/laws/show/1401-19 (дата звернення: 22.06.2020).

3. Про судоустрій і статус суддів : Закон України від 2 червня 2016 р. № 1402-VIII. URL: https: / /zakon.rada.gov.ua/ laws/show/1402-19 (дата звернення: 22.06.2020).

4. Судова реформа. URL: https://minjust.gov.ua/ cat_414 (дата звернення: 22.06.2020).

5. Конституція України : Закон від 28 червня 1996 р. URL: https://zakon.rada.gov.ua/laws/show/254\%D0\%BA/96\%D0\%B2\%D1\%80/print (дата звернення: 22.06.2020).

6. Про державну службу : Закон України від 10 грудня 2015 р. № 889-VIII. URL: https: / /zakon.rada.gov.ua/laws/ show/889-19 (дата звернення: 22.06.2020).

7. Про запобігання корупції : Закон України від 14 жовтня 2014 р. № 1700-VII. URL: https://zakon.rada.gov.ua/laws/ show/1700-18/ (дата звернення: 22.06.2020).

8. Кодекс законів про працю України : Закон України від 10 грудня 1971 р. № 322-VIII. URL: https://zakon.rada.gov.ua/ $\mathrm{rada} / \mathrm{show} / 322-08$ (дата звернення: 22.06.2020).

9. Судова влада. URL: https://uk.wikipedia.org/wiki/ \%D0\%A1\%D1\%83\%D0\%B4\%D0\%BE\%D0\%B2\%D0\%B0_\%D0\%B2\%D0\% BB\%D0\%B0\%D0\%B4\%D0\%B0 (дата звернення: 22.06.2020).

10. Грошевский Ю., Марочкин И. Органы судебной власти в Украине. Киев: Ин Юре, 1997. 20 с.

11. Назаров І. Судові системи країн Європейського союзу та України: порівняльно- правовий аналіз : автореф. дис. ... докт. юрид. наук: 12.00.10. Харків, 2011. 39 с.

12. Фоміна М. До питання розмежування понять «судова система» та «судоустрій». Часопис Київського університету права. 2013. № 1. С. 67-69.

13. Куйбіда Р. Реформування правосуддя в Україні: стан і перспективи. Київ : Атіка, 2004. 288 с.

14. Квасневська Н. Поняття судової системи України: сучасний погляд. Форум права. 2015. № 5. С. 101. URL: http://nbuv.gov.ua/UJRN/FP_index (дата звернення: 22.06.2020)

15. Туркіна І. Типології правових систем і роль органів судової системи в механізмі держави. Теоретичні та прикладні питання державотворення. 2012. Вип. 10. С. 64-76. URL: http://nbuv.gov.ua/UJRN/tppd_2012_10_6 (дата звернення: 22.06.2020).

16. Москвич Л. Напрями оптимізації судоустрою України. Вісник Верховного Суду України. 2011. № 4 (128). С. 25.

17. Туркіна І. Сутність судової влади як особливої сфери державної діяльності. Публічне управління. 2012. № 2. URL: http://www.kbuapa.kharkov.ua/e-book/putp/2011-2/ doc/1/05.pdf (дата звернення: 22.06.2020).

18. Макаровець А. Вдосконалення адміністративного законодавства, яке реґламентує діяльність апарату суду в Україні. Верховенство права : международный научный журнал. 2018. № 1. С. 50-56.

19. Типове положення про апарат суду : наказ Державної судової адміністрації України від 8 лютого 2019 p. № 131. URL: https://zakon.rada.gov.ua/rada/show/ v0131750-19 (дата звернення: 22.06.2020).

20. Золотарьова Я. Адміністративно-правовий статус державних службовців судових органів: теоретичний аспект. Науковий вісник Ужгородського національного університету. Серія «Право». 2015. Вип. 34 (2). С. 80-83.

21. Захорольных Н. Особенности административно-правового статуса арбитражного управляющего. Юридическая наука. 2012. № 4. С. 69-73. 
22. Понятие и структура административно-правового статуса судебных органов Украины. Visegrad journal. URL: http:// vjhr.sk/archive/2015_4_1/13.pdf (дата звернення: 22.06.2020).

23. Організація роботи суду : навчальний посібник / І. Марочкін та ін. Харків : Право, 2012. 256 с.

24. Юрченко Ю. Адміністративно-правове регулювання у сфері судочинства. Правознавство. Випускний курс. Київ : Університет «Україна», 2013. 296 с.

25. Василенков П. Органы советского государства и их система на современном этапе. Москва : Моск. гос. ун-т, 1967. 304 c.

26. Баронін Д. Суд в системі органів державної влади. URL: http://www.jurnaluljuridic.in.ua/archive/2014/4/8. pdf (дата звернення: 22.06.2020).
27. Разводовський В. Особливості нормативно-правового регулювання державноуправлінських відносин у транспортній сфері. Вісник Національного університету внутрішніх справ. 2003. Вип. 23. С. 167-174.

28. Матвійчук А. Визначення адміністративно-правового регулювання у сфері забезпечення регуляторної політики. Підприємство, господарство і право. 2018. № 11. С. 121-124.

Бабчук А. Д., аспірант I курсу кафедри адміністративного права та адміністративного процесу одеського державного університету внутрішніх справ 